\title{
The power of deep reading and mindful literacy: An innovative approach in contemporary education
}

\author{
Maureen P. Hall, \\ Aminda $\mathrm{O}^{\prime}$ Hare, \\ Nicholas Santavicca \\ University of Massachusetts Dartmouth \\ Libby Falk Jones, \\ Berea College, Kentucky
}

\begin{abstract}
This paper explores mindfulness as an innovation for improving literacy skills of deep reading. More specifically, this paper describes a case study of a deep reading intervention where graduate education students participated in an eight-week deep reading training. As an embodied practice, deep reading serves to awaken and evoke the reader's voice, helping the learner to make meaning as a whole person immersed in the embodied nature of language. Deep reading, as other contemplative practices, requires persons to go inside, to find meaning, to know themselves, and to connect to others (Barbezat \& Bush, 2014). Unlike many other contemporary approaches in education, deep reading draws upon the involvement of the whole body and mind. Deep reading provides a conduit for stretching the human capacity for imaginative thought, shows promise for developing cognition, quiets the chaos of a distracted society, and, overall, serves to humanize the educational process.
\end{abstract}

\section{El poder de la lectura profunda y la alfabetización consciente: acercamientos innovadores a la educación contemporánea}

\section{Resumen}

Este trabajo analiza la atención consciente como una innovación para mejorar las capacidades lectoras de la lectura profunda. Particularmente, describe un estudio de caso de una práctica de lectura profunda en la que estudiantes de posgrado participaron en una capacitación de ocho semanas. Como práctica corporeizada, la lectura profunda sirve para despertar y evocar la voz del lector, ayudándole a construir significado desde la perspectiva de un individuo integral inmerso en la naturaleza manifiesta del lenguaje. La lectura profunda, como otras prácticas contemplativas, requiere que las personas se adentren, encuentren sentidos, se conozcan y se conecten con los demás (Barbezat y Bush, 2014). A diferencia de otras técnicas educativas contemporáneas, la lectura profunda recurre al involucramiento de todo el cuerpo y la mente. Ofrece un conducto

\section{Keywords}

Literacy, educational alternatives, diversified education, deep reading, cognitive approach, reading comprehension.
Palabras clave Alfabetización, alternativas educativas, educación diversificada, lectura, cognoscitivismo, comprensión de textos.

Recibido: 20/02/2015 Aceptado: 06/03/2015 
para aumentar la capacidad humana del pensamiento imaginativo, y resulta prometedor como herramienta para desarrollar la cognición, aquietar el caos de una sociedad distraída y, sobre todo, para humanizar el proceso educativo.

\footnotetext{
"Welcome to the attention economy, in which the new scarcest resource isn't ideas or even talent, but attention itself".

-Davenport and Beck (cited in Adelman, 2014)
}

\begin{abstract}
$\Lambda$ ttention, as pointed out by Davenport and Beck (2001) and Adelman (2014), is in "scarce" supply in $21^{\text {st }}$ century education. Research from psychology has demonstrated that on average, individuals' minds wander once every 30 seconds (Kane et al., 2007; Killingsworth \& Gilbert, 2010), making time-on-task and focused attention a critical resource for classroom learning and education. Now, more than ever, there is a call for new approaches to improve teaching and learning and to respond to the "distracted" society in which we live.

The human quality of paying attention is at the heart of individual growth and of empathy with others. As Maxine Greene (2007) sees it, the classroom can foster an "ability to come close to someone else, to see through his eyes, to see the work, the preciousness of that other human being" (p. 6). Philosopher and mystic Simone Weil $(1951,1973)$ notes that the love of one's neighbor as well as the love of God is based on attention. "The capacity to give one's attention to a sufferer is a very rare and difficult thing; it is almost a miracle; it is a miracle," Weil writes (p. 114). The embodied and interactive space of the classroom is a place where teachers and students can promote a kind of learning "wide-awakeness," as Greene suggests. Jon Kabat-Zinn describes mindfulness as bringing focused attention to momentby-moment experiences (1990), and this is a kind of "wide-awakeness" that is often absent in today's classrooms.

As a conduit for improving attention, mindfulness holds possibilities for deepening learning and thereby improving contemporary education. Mindfulness holds power for helping teachers and learners because it can "enhance and support self-knowledge, self-regulation, and the freedom to co-create with others' internal states and interpersonal relationships that are coherent and emotionally regulated" (Bai, Scott \& Donald, 2009, p. 332). This paper explores the terrain of mindfulness in terms of its capaciousness for improving literacy skills of deep reading. More specifically, this paper discusses a classroom deep reading intervention where students participated in an eight-week deep reading training.
\end{abstract}




\section{Case study in deep reading and mindful literacy}

The case study described in this paper involved a deep reading intervention, proving a way to bridge theories of contemplative practice and mindfulness into classroom practice. In this case study, students in a Reading Literacy and Content Methods graduate education course were led through eight weeks of daily deep reading practice. Deep reading falls within the broader scope of contemplative practices. It is the slowed, thoughtful, and intentional reading of material with reflection on how it relates to the self and broader communities (Birkerts, 1994). Through the practice of deep reading, several foundational skills for developing as a learner and a productive member of society are developed (e.g., Kid \& Castano, 2013). The development of these skills can be scaffolded by individual and group activities involving deep reading.

Each week, the class was introduced to new ways of understanding through deep reading. These ways of understanding were modeled on Bloom's Taxonomy (1956), which privileges creating varying kinds of reasoning skills required of learners. These foci included: describe, explain, argue, justify, apply, analyze, evaluate, and synthesize. On their own, students were asked to do a practice of deep reading on the assigned course material, picking one or two paragraphs on which to focus and reflect each day. Students provided their reflections on their experiences with deep reading, their understanding of the course material, and their insights into their own learning processes in their Deep Reading Reflective Online Journals. The assigned reading materials for the deep reading practice were from research articles from neuroscience, education and psychology, as well as poetry and fiction. These reading assignments all held relevance to the larger topic of contemplative practices in education and were tied to the course objectives in terms of understanding reading and reading processes.

\section{Excerpts from students' deep reading reflective online journals}

What follows are three excerpts from different participants' Deep Reading Reflective Online Journals. These excerpts evidence challenges, changes, and insights that these students noticed about their own reading and learning processes through the 8-week deep reading intervention. One participant, near the beginning of the 8-week treatment, wrote about the struggle to focus:

I noticed I would find myself just reading words on the paper and not actually 'reading' what was on the paper. Instead, 
my mind was too busy thinking about what was for dinner, to make sure to switch the laundry, and even just thinking about what unfolded during my day.

Another excerpt from a different participant evidenced a growing evolution in awareness of process. S/He noted:

I was not always able to find a perfect quiet to read in, but I was successful in placing myself in a focused state to deeply read ... I began to find it easier to negotiate distraction.

Similar to the first excerpt, this participant also wrote about finding ways to bypass or "negotiate" distractions and thereby gain deeper focus into and understanding of the texts being read.

The third excerpt from a participant's journal articulates the deep reading process as it evolved. This participant noted:

Throughout my reflective online journal writing and attempt at deep reading, I was able to reflect and understand my own awareness (or lack of at times) in my own learning. At times it was difficult because I felt as if my mind would constantly wander and I would have to redirect my focus on whatever it was I was reading. Eventually, I felt as if it became easier because I was able to recognize when a distracting thought was developing.

This participation "journeyed" from mind-wandering to new awareness and possibilities for self-reflection.

These excerpts from participants' Deep Reading Reflective Online Journals show promise for tapping into abilities for focused attention on reading, one that promotes both deeper understanding of the text and of the self.

\section{Implications of the deep reading case study}

Through this ongoing and reflective process, as partly evidenced by the students' Deep Reading Reflective Online Journals, several skills were developed. Early on, students had to work on creating a practice of sustained, focused attention. As evidenced in the excerpts from the students' journals, they struggled with overcoming the common experience of reading on "autopilot" and having to go back to figure out what the skimmed-over content was. However, dedicating 10-15 minutes a day to reading in an intentional, controlled manner began to strengthen their attentional control. We see this step as crucial to the application of contemplative practices in the classroom. Often, educators want their students to jump right in to deep reflection, but they cannot 
learn to run before they can walk, and without developing these foundational skills in attention, students can find these practices frustrating.

Following the development of attention, students began to develop deepened learning and understanding of the course materials. The weekly foci for ways of understanding helped them to investigate reading materials through a new lens, as well as reflect on which ways of understanding were easier versus more difficult for them. Preliminary qualitative findings evidenced that students moved from externalizing the course materials and concepts to internalizing them by integrating them with their own experience and self-understanding.

Finally, when the class met each week, students discussed their experiences with their daily practice as a group. This allowed for the development of understanding of others' experiences, compassion, and feelings of community with one another. Students found that not all of them had related to the readings in the same ways or connected them to the same conceptual information for the course. Further, students' communication skills with each other improved as well. The daily reflection they had done on their own meant that they came to class already knowing their own insights into the reading and the experience. This enabled them to engage in deep listening to others by allocating their attention to what was actually being said, rather than to preparing a response to what was being said. This qualitative case study, with understandings based on the observations of the class instructor and an external observer who reviewed the reflective journals, strongly supports the integration of contemplative techniques in classroom learning to help students develop both cognitively and affectively.

\section{A deep history of deep reading}

The deep reading practiced by students in this study draws on the ancient tradition of lectio divina, best translated as "spiritual reading" or "sacred reading." The practice of lectio divina originated with St. Benedict, who in his sixth-century Rule specifies that Benedictine brothers should have daily periods of "prayerful reading" done in silence and privacy (The Rule of St. Benedict, n.d., 48:3-5). Such reading, the Rule notes, is necessary for the "cultivation of virtues" (73:2-6). Spiritual reading, according to twelfth-century Benedictine Abbot Peter of Celle, is "the soul's food, light, lamp, refuge, consolation." He likens sacred reading to a bread box containing a variety of breads so that all who approach it will be "filled with the refreshment that suits them" (Peter of Celle, 1987). Such reading, according to twelfth-century Cistercian Abbot William of St. Thierry, is "definite" rather than 
"haphazard": the latter, "constantly varied and as if lighted on by chance does not edify but makes the mind unstable; taken into the memory lightly, it goes out from it even more lightly" (William, 1971, v. 120). Such haphazard reading is like a passing acquaintanceship; while the "attentive study" that is lectio divina is like friendship. A contemporary Cistercian Abbot, Bernardo Olivera (1993), defines lectio divina as "a pilgrimage of words," a meditative reading that is transformative.

Several centuries after Benedict described lectio divina in his Rule, the monastic order of Carthusians extended the practice into four parts: reading, meditation, prayer, and contemplation (Lichtmann, 2005, p. 23). In the first movement, reading, we approach the text thoughtfully and slowly, turning "a just and loving gaze on reality" (Lichtmann, 2005, p. 12). To read in this way is to pay attention, to wait, expectantly, in the presence of words, for them to speak to us. Simone Weil $(1951,1973)$ describes attention as a deliberate passivity or openness: "Attention consists of suspending our thought, leaving it detached, empty, and ready to be penetrated by the object" (p. 111). The second movement, meditation, involves sitting with the text, turning it over, examining it from different angles, seeking its "inner meaning" (Lichtmann, 2005, p. 24). William of St. Thierry (1971) suggests memorizing part of the reading, so it can be "taken as it were into the stomach, to be more carefully digested and brought up again for frequent rumination." The third stage, prayer, engages the heart, whether through voice or silence, while the fourth stage, contemplation, is a vision, a going-beyond, transcendence (Lichtmann, 2005, p. 24; Olivera, 1993). James Finley (1978) summarizes lectio divina through a metaphor:
A man drops a rare diamond in the leaves of the forest floor. Carefully, he kneels down. One by one he lifts each leaf. Slow- ly he searches, knowing his lost treasure is in the leaves. And this is how it is that we must read, listen to another and wait in silence. (p. 126)

The practice of lectio divina has clear implications for educational practice. The movement of such reading is dialogic, not static, as Olivera notes (1993). In The Teacher's Way: Teaching and the Contemplative Life, Maria Lichtmann (2005) argues that lectio divina can become a means not only of reading texts, but of reading our students and ourselves, allowing ourselves to be changed by these readings. This understanding of "reading" accords with the dialogic, participatory, and liberatory educational theories of Paolo Freire (as cited in Watkins, 2004):

I say that reading is not just to walk on the words, and it is not flying over the words either. Reading is re-writing what we 
are reading. Reading is to discover the connections between the text and the context of the text, and also how to connect the text/context with my context, the context of the reader. But for me, what is indispensable, is to be critical. Criticism creates the necessary intellectual discipline, asking questions to the reading, to the writing, to the book, to the text. We should not submit to the text or be submissive in front of the text. The thing is to fight with the text, even though loving it, no? (p. 55)

Deep reading can not only slow us down and help us to attend to what's important. It can also help us to love texts and the subjects we know through them. Deep reading can inspire in us a reverence for word and thing and for one another.

\section{The need for deep reading}

In the $21^{\text {st }}$ century, the human sense of time and space is changed; it is a place where procedural literacy, or manipulation of devices, trumps verbal literacy. Our society, as Waxler and Hall (2011) point out, "elevates procedural literacy rather than verbal literacy, fostering the celebration of speed and boundless exhilaration rather than duration and deep thinking" (p. 171). Instead of focusing on stretching one's capacity for imagination and developed cognition, procedural literacy focuses on the how of something instead of a deeper look at why.

Deep reading is a skill that is not privileged in a digital society that promotes skimming and fast consumption of information. Mara Adelman (2014) characterizes the $21^{\text {st }}$ century as the age of "solitude loss." She claims that "we are wired as never before and distracted to death" (p. 54). Waxler and Hall (2011) add to Adelman's description and explain how the media-saturated world affects those living in it. Students are "drawn to visual sensation and, as a result, lose the fundamental connection with the mystery of their own voice and imagination" (p. 67). This is why we need to rejuvenate some of the traditions in education, ones that are

rooted in the belief that the goal of education is to create a compassionate community of concerned human beings, a democracy that celebrates human beings as ends in themselves, not as means to some other end such as profits or winning. (p. 7)

The practice of deep reading is not a new idea in the world, but it is something that has fallen to the wayside with modern times and our society's obsession with procedural literacy over verbal literacy. We need new approaches that promote deep 
engagement with the world of ideas, and the implications of these ideas for a well-lived life. Multicultural education, in particular, can benefit from such pedagogical approaches.

\section{Mindfulness as an innovation for multicultural education}

In $21^{\text {st }}$ century multicultural education, mindfulness can help develop a necessary critical relationship that is enduring, aware, and omnipresent. Multicultural education was originally conceptualized as a counter-hegemonic alternative for decolonizing the curriculum and transforming class and life outside the classroom (Fellin, 2000). Many early scholars of multicultural education called for a critical pedagogy that is a "way of thinking about, negotiating, and transforming the relationship among classroom teaching, the production of knowledge, the institutional structure of the school, and the social and material relations of the wider community, society, and nation-state" (Kozol, 1991; Ladson-Billings, 1994; McClaren, 1994). The principles challenged problem-posing pedagogy and promoted critical contemplative thinking. The essence of multicultural teaching revolved around deep listening, reading, and ultimately constructing a deep relationship around multicultural issues; simple cause and effect solutions do not interrogate the sociocultural nuances of our varied identities.

Current practices in multicultural education have betrayed the critical problematizing. Multicultural education has become rooted in deficit models, high stakes testing, knowledge standardization, strategy implementation, and teaching to the test (Darder, 2015). We also find ourselves faced with a society that has become more Western-ethnocentric with individualism, efficiency, project/ solution-based curricula. This leads to the negation of support of communal strategies, ancestral knowledge frameworks, spiritual traditions, and cultural-responsive teaching.

Mindfulness through deep reading can begin to liberate those educators who feel entrapped by resistance and legitimacy claims of paradigms and assumptions that rest inside well-intended but still colonizing social values and epistemologies of prejudice. There is no question that current trends in multicultural education try to normalize in the name of power, democracy, and progress. Through mindfulness practices like deep reading, we find an innovation, a point of departure to develop a relationship that turns away from the trends in multicultural education and refocuses multicultural education to be critical and contemplative.

Contemplative practice is one of the most powerful transformative interventions developed by humanity. It has been specifically designed to move human cognition from a delusory view of reality to a true one: that is, to one in which the profound inter- 
connectedness of reality is directly perceived. Global conflict has its deep source in the privileging of worldviews, in the reification of our particular understanding and the objectification of the other. Such ways of seeing our world are, at root, dysfunctional and divisive (Rendon, 2006). Contemplative practice works on the human psyche to shape attention into a far suppler instrument, one that can appreciate a wide range of worldviews and even sustain the paradoxes of life, ultimately drawing life's complexity into a gentle, non-judgmental awareness.

\section{Deep reading as contemplative practice: Cognitive effects}

Deep reading requires human beings to call upon and develop attentional skills, to be thoughtful, and fully aware; it helps them to create and understand their own identity. Deep readers navigate from the words on the page to the self. Deep reading is interactive: it awakens and evokes the reader's voice, and it insists on the involvement of the whole body and mind. It is an embodied practice. We make meaning as whole persons immersed in the embodied nature of language. Deep reading, as other contemplative practices, requires persons to go inside, to find meaning, to know themselves, and to connect to others (Barbezat \& Bush, 2013).

Deep reading as contemplative practice holds some power for both quieting the chaos of a modern life and also providing deeper focused attention and connectedness with others. These implications of contemplative practice are supported by findings from the field of cognitive neuroscience. It has been found that when an individual engages in deep reading, areas of the brain associated with the conceptualization of the self become more active (e.g. Whitney et al., 2009). These findings support the idea that individuals internalize material that is deeply read and use it as a method for exploring the self. Additionally, when individuals are relating their personal experiences to the experience of others, the mirror neuron system of the brain becomes active (e.g., Carr, Iacoboni, Dubeau, Mazziotta, \& Lenzi, 2003). Theoretically, the act of relating material to one's sense of self through deep reading, and then relating that material to one's understanding of others, allows one to feel more connected to others both psychologically and through the development of new neural pathways. Immordino-Yang (2008) and others (Dehaene, 2009; Wolf, 2007) add to the growing body of scientific research including understanding how mirror neurons help to activate deep reading and empathy for others (Hruby \& Goswami, 2011). Deep reading has the unique capacity to teach human beings how best to create a narrative self, and, when coupled with focused conversation, how best to 
create a community for learning, a neighborhood where students and teachers can negotiate meaning together.

\section{Conclusion}

Deep reading as a contemplative approach in education provides dynamic avenues for enriching and broadening education in ways that value the whole person-body, mind, and spirit. By integrating mind and body through awareness of the present moment, these practices can help teachers and students gain insight into themselves, others, and the human condition itself (Palmer \& Zajonc, 2010). These practices not only help students develop foundational cognitive skills that can translate to other academic endeavors, but they also help with the development of social and emotional skills, such as theory of mind, connectedness and community, and compassion. Deep reading as a contemplative practice holds great promise for addressing issues of attention, and, in many ways attempting to heal our distracted society. A practice of deep reading activates imaginative capacities, one that "invites all participants into the dialogue becomes an enchanted space where participants' thinking-their brains-can actually be changed" (Waxler \& Hall, 2011, p. 62). Deep reading as contemplative practice is an innovation in contemporary education, one which holds power to humanize the learning community and deepen learning opportunities for students and teachers alike.

\section{References}

Bai, H., Scott, C., \& Donald, B. (2009). Contemplative pedagogy and revitalization of teacher education. Alberta Journal of Educational Research, 55(3), 319-334.

Barbezat, D. P., \& Bush, M. (2013). Contemplative practices in higher education: Powerful methods to transform teaching and learning. Hoboken, NJ: John Wiley $\&$ Sons.

Bloom, B. S. (Ed.). (1956). Taxonomy of educational objectives (vol. 1). Cognitive domain. New York, NY: McKay.

Birkerts, S. (1994). The Gutenberg elegies: The fate of reading in an electronic age. Boston, MA: Faber and Faber.

Carr, L., Iacoboni, M., Dubeau, M., Mazziotta, J. C., \& Lenzi, G. L. (2003). Neural mechanisms of empathy in humans: A relay from neural systems for imitation to limbic areas. Proceedings of the National Academy of Sciences, 100, 5497-5502.

Dehaene, S. (2009). Reading in the brain: The science and evolution of a human invention. New York, NY: Viking.

Finley, J. (1978). Merton's palace of nowhere: A search for God through awareness of the true self. Notre Dame, IN: Ave Maria Press. 
Greene, M. (2007). Imagination, oppression and culture/creating authentic openings. Self-published essay. Retrieved on March 21, 2010, from: www.maxinegreene.org/ pdf/articles/downloader.php?file...oc.pdf

Hruby, G. G., \& Goswami, U. (2011). Neuroscience and reading: A review for reading education researchers. Reading Research Quarterly, 46(2), 156-172.

Immordino-Yang, M. H. (2008). The smoke around mirror neurons: Goals as sociocultural and emotional organizers of perception and action in learning. Mind, Brain, and Education. 2(2), 67-73.

Kabat-Zinn, J. (1990). Full catastrophe living: Using the wisdom of your body and mind to face stress, pain and illness. New York, NY: Delacorte.

Kane, M. J., Brown, L. H., McVay, J. C., Silvia, P. J., Myin-Germeys, I., \& Kwapil, T. R. (2007). For whom the mind wanders, and when: An experience-sampling study of working memory and executive control in daily life. Psychological Science 18(7), 614-621.

Kidd, D. C., \& Castano, E. (2013). Reading literacy improves theory of mind. Science, 342, 377-380.

Killingsworth, M. A., \& Gilbert, D. T. (2010). A wandering mind is an unhappy mind. Science, 330, 932.

Ladson-Billings, G. (1994). The dreamkeepers: Successful teachers of African American children. San Francisco, CA: Jossey-Bass.

Lichtmann, M. (2005). The teacher's way: Teaching and the contemplative life. New York, NY: Paulist.

Olivera, B. (1993). Lectio Divina. Order of St. Benedict. Retrieved from: http://www.osb. org/lectio/olivera.html

Palmer, P. J., \& Zajonc, A. (2010). The heart of higher education: A call to renewal transforming the academy through collegial conversations. San Francisco, CA: Jossey Bass.

Peter of Celle (1987). Selected Works, On affliction and reading. (H. Feiss Trans.), OSB. Kalamazoo, MI: Cistercian Publications. 135. Retrieved from: http://vultuschristi. org/index.php/2014/11/convertisti-planctum-meum-in-gaudium-mihi/

The Order of St. Benedict: William of St. Thierry on Lectio Divina. Retrieved from: http://www.osb.org/lectio/thierry.html

The Rule of St. Benedict, excerpts. Order of St. Benedict: Lectio Divina; Excerpts from The Rule of St. Benedict. Retrieved from: http://www.osb.org/lectio/rbonld.html

Watkins, M. (2004). Liberating soul sparks: Psyche, classroom, and community. In Dalke, A., \& Dixson, B. (Eds.), Minding the light: Essays in friendly pedagogy. Berne, $\mathrm{CH}$ : Peter Lang International Academic Publishers.

Waxler, R. P., \& Hall, M. P. (2011). Transforming literacy: Changing lives through reading and writing. Bingley, UK: Emerald Insight Publishing.

Weil, S. (1951; 1973). Reflections on the right use of school studies with a view to the love of God: Waiting for God. New York, NY: Harper.

Whitney, C., Huber, W., Klann, J., Weis, S., Krach, S., \& Kircher, T. (2009). Neural correlates of narrative shifts during auditory story comprehension. Neuroimage, 47 , 360-366.

William of Saint Thierry (1971). The Golden Epistle: A Letter to the Brethren at Mont Dieu 1.120-124. (O. Berkeley, Trans.). The Works of William of St. Thierry, Cistercian Fathers 12. Spencer, MA: Cistercian Publications (pp. 51-52).

Wolf, M. (2007). Proust and the squid: The story and science of the reading brain. New York, NY: Harper \& Collins.

Center for Contemplative Mind in Society (2000-2015). www.contemplativemind.org/ practices 